\title{
Impact of 20-day strike in Polokwane Hospital (18 August - 6 September 2010)
}

\author{
M M Z U Bhuiyan, A Machowski
}

Background. Doctors' strikes have a negative effect on hospital performance indicators. Hospital mortality during such strikes is the most important indicator.

Objective. To determine the effects of the 2010 strike on Polokwane Hospital.

Methods. Information was collected from the Hospital Information System, Polokwane Hospital Casualty Department, wards and theatres.

Results. During the 20-day strike, a total of 262 patients were admitted to Polokwane Hospital, with 40 patients to the surgical department; 96 operations were performed in the hospital and 40 in the surgical department; and 50 deaths were reported in the hospital ( 8 deaths in the surgical department). During 20 days of a non-striking period in May 2010, there were 975 admissions to the hospital, with 125 to the surgical department. In the entire hospital, 340 operations were performed, and 79 in the surgical department. For this period, 61 deaths were reported in the hospital and 12 in the surgical department.

Conclusions. The total number of patients admitted to the hospital and the surgical department during the strike was significantly lower than during a non-striking situation. Total mortality during the strike in Polokwane Hospital decreased, compared with the normal situation, but it increased when judged against emergency cases. However, when mortality was qualified by the number of admissions, it showed a significant increase. Strikes seriously and significantly affect service delivery.

S Afr Med J 2012;102(9):755-756. DOI:10.7196/SAMJ.6045
Public health sector strikes have a negative effect on all of society, with the poor suffering the most, especially when a health service is paralysed. In-hospital mortality during doctors' strikes appears to be the key indicator in evaluating the consequences of such strikes on service delivery. The literature reports decreased in-hospital mortality during doctors' strikes, ${ }^{1-3}$ but an increased mortality during hospital nurses' strikes in the USA has been reported. ${ }^{5}$ We assessed the effect of a 20-day doctors' strike in Polokwane Hospital, Limpopo Province, during which the peripheral hospitals of Limpopo Province were rendered almost non-functional, and only the Polokwane Mankweng Hospital Complex (PMCH) provided emergency services for the entire province. $\mathrm{PMCH}$ is a tertiary institution receiving patients from Limpopo Province. In 2010, the province had an estimated population of 5.5 million, of whom $90 \%$ had no medical aid, therefore depending heavily on public hospitals for healthcare.

\section{Objectives}

We studied the impact of a health professionals' 20-day strike in Polokwane Hospital, and compared performance indicators during the strike with a non-striking period.

\section{Methods}

Data were collected during the 20-day strike (18 August 2010 - 6 September 2010) from the Hospital Information System (HIS), Polokwane Hospital Casualty Department (PHCD), surgical wards and theatres. Coomparison data for a non-striking period were collected from HIS, PHCD, wards and theatres during a randomly

Department of General Surgery, Polokwane Mankweng Hospital Complex and University of Limpopo, Polokwane M M Z U Bhuiyan, FRCSG, MMed

A Machowski, MD, $\mathrm{PhD}$ selected 20-day period in May 2010. Data included the performance indicators referred to: admissions, operations and deaths.

\section{Results}

During the 20-day strike, 262 patients were admitted to Polokwane Hospital and 40 patients to the surgical department. In the entire hospital, 96 operations were done and 40 in the surgical department; 50 deaths were reported throughout the hospital and 8 deaths in the surgical department. During the 20 days of a non-striking period in May 2010, there were 975 admissions to the hospital and 125 to the surgical department; 340 operations were done throughout the hospital and 79 in the surgical department; 61 deaths were reported throughout the hospital and 12 deaths in the surgical department (Tables 1 and 2).

\section{Discussion}

Service delivery may be expected to be affected seriously and deleteriously during health professional strikes. However, the literature reports a lowering of mortality ${ }^{1-3,6}$ or no change $e^{4,7}$ when doctors strike; but a $19.4 \%$ increase in mortality during hospital striking periods by nurses in New York, USA, between 1984 and 2004 has been reported. ${ }^{5}$

A review by Cunningham et al. spanning 1976 - 2003 reported that mortality reduced or stayed the same. ${ }^{1}$ In Israel in 1973, when doctors went on strike for a month, mortality decreased by 50\%. In 1976 in Bogota, Columbia, when medical doctors went on strike for 52 days, providing only emergency care for patients, the death rate dropped by $35 \%$. In the same year, the Los Angeles County doctors' strike resulted in an $18 \%$ drop in mortality. As soon as the strike was over, the death rate returned to its usual levels..$^{1-3}$ Available information suggests that when doctors strike, mortality is reduced. This contradiction to expectations might be cynically and inaccurately held against the medical profession. Comprehensive analysis shows that when a strike takes place, most emergency cases are attended by non-striking personnel or by other institutions substituting for striking hospitals. Elective procedures are deferred until the strike is over. Most cases are treated outside the hospitals, by general practitioners and private clinics. The mortality from elective surgical procedures, which are 
Table 1. Performance indicators during the 20-day strike, and 20-day non-strike in May 2010, in Polokwane Hospital, Limpopo

\begin{tabular}{|c|c|c|c|}
\hline & $\begin{array}{l}\text { During 20-day } \\
\text { strike }\end{array}$ & $\begin{array}{c}\text { During } 20 \text { days non-strike May } 2010 \\
\text { (combined elective and emergency) }\end{array}$ & $\begin{array}{c}\text { During } 20 \text { days non-strike May } 2010 \\
\text { (emergency cases only) }\end{array}$ \\
\hline Number of patients admitted to hospital & 262 & 975 & 382 \\
\hline $\begin{array}{l}\text { Number of patients admitted to surgical } \\
\text { department }\end{array}$ & 40 & 125 & 73 \\
\hline Number of operations in entire hospital & 96 & 340 & 177 \\
\hline Number of operations in surgical department & 40 & 79 & 27 \\
\hline Number of deaths in entire hospital & 50 & 61 & 30 \\
\hline Number of deaths in surgical department & 8 & 12 & 7 \\
\hline
\end{tabular}

\section{Table 2. Performance indicators in Polokwane Hospital; comparison of non-striking period with strike period}

\begin{tabular}{|c|c|c|c|c|c|}
\hline & \multicolumn{2}{|c|}{ Non-striking situation } & \multirow[b]{2}{*}{$\begin{array}{c}\text { Strike } \\
(N)\end{array}$} & \multicolumn{2}{|c|}{ Comparison } \\
\hline & $\begin{array}{l}\text { Combined elective } \\
\text { and emergency }\end{array}$ & Emergency only & & $\begin{array}{l}\text { Strike/non-striking situation } \\
\text { (combined elective and emergency) }\end{array}$ & $\begin{array}{l}\text { Strike/non-striking } \\
\text { ) situation (emergency) }\end{array}$ \\
\hline $\begin{array}{l}\text { Number of patients admitted } \\
\text { to hospital }\end{array}$ & 975 & 382 & 262 & Reduced by $63 \%$ during strike & $\begin{array}{l}\text { Reduced by } 31 \% \text { during } \\
\text { strike }\end{array}$ \\
\hline $\begin{array}{l}\text { Number of patients admitted } \\
\text { to surgical department }\end{array}$ & 125 & 73 & 40 & $\begin{array}{l}\text { Reduced by } 68 \% \text { during strike } \\
(p 0.301)\end{array}$ & $\begin{array}{l}\text { Reduced by } 45 \% \text { during the } \\
\text { strike ( } p 0.298)\end{array}$ \\
\hline $\begin{array}{l}\text { Number of operations in } \\
\text { entire hospital }\end{array}$ & 340 & 177 & 96 & $\begin{array}{l}\text { Reduced by } 72 \% \text { during the strike } \\
(p 0.595)\end{array}$ & $\begin{array}{l}\text { Reduced by } 46 \% \text { during the } \\
\text { strike ( } p 0.014 \text { ) }\end{array}$ \\
\hline $\begin{array}{l}\text { Number of operations in } \\
\text { surgical department }\end{array}$ & 79 & 27 & 40 & $\begin{array}{l}\text { Reduced by } 49 \% \text { during the strike } \\
\left(p 0.001^{*}\right)\end{array}$ & $\begin{array}{l}\text { Increased by } 48 \% \text { during the } \\
\text { strike ( } p 0.001)\end{array}$ \\
\hline $\begin{array}{l}\text { Number of deaths in entire } \\
\text { hospital }\end{array}$ & 61 & 30 & 50 & $\begin{array}{l}\text { Reduced by } 18 \% \text { during the strike } \\
(p 0.001)\end{array}$ & $\begin{array}{l}\text { Increased by } 67 \% \text { during the } \\
\text { strike }(p 0.001)\end{array}$ \\
\hline $\begin{array}{l}\text { Number of deaths in surgical } \\
\text { department }\end{array}$ & 12 & 7 & 8 & $\begin{array}{l}\text { Reduced by } 33 \% \text { during the strike } \\
\left(p 0.079^{*}\right)\end{array}$ & $\begin{array}{l}\text { Increased by } 14 \% \text { during the } \\
\text { strike }\left(p 0.227^{\star}\right)\end{array}$ \\
\hline
\end{tabular}

not performed during strikes, also reduces the figure. However, the reduction of in-hospital mortality is compensated by an increased patient death rate outside of the striking hospitals - in other institutions or in patients' homes. Reports reflect only in-hospital mortality, and not total mortality of the entire population in the striking areas. The reported mortality is represented by total number of deaths, and is not qualified by the more appropriate numbers of admissions.

The strike in Polokwane evidently lowered the quality of service delivery; there was an overall reduction in the number of admissions and operations in the hospital. During the strike, mortality reduced but not proportionately to admissions, either in the surgical department or the entire hospital. Hospital mortality during the strike, when correlated with numbers of admissions, increased threefold for the hospital as a whole and, in the surgical department, mortality doubled. It is probable that further analysis of mortality in the population outside the hospital would elucidate the true reflection of actual mortality and hence the real consequences of a health professionals strike in our population.

\section{Conclusions}

The total number of patients admitted to Polokwane Hospital and the surgical department during the strike was significantly lower than during non-striking circumstances. Total mortality during the strike decreased in comparison with normal conditions, but increased when judged by emergency cases. However, when mortality was qualified by the number of admissions, a significant two- to threefold increase was apparent. The strike seriously and significantly affected service delivery (elective admissions and operations) in Polokwane Hospital. Every effort must be made to avoid strikes in health services institutions.

Acknowledgements. We thank Mrs R Mavhungu (research assistant) for her contribution to collecting data from theatres, and $\mathrm{Mr} \mathrm{T} S$ Ntuli for his contribution of statistical inferences.

\section{References}

1. Cunningham SA, Mitchell K, Narayan KM, Yusuf S. Doctors' strikes and mortality: a review. Soc Sci Med 2008;67(11):1784-1788

2. Ellencweig AY, Ginat-Israeli T. Effects of the Israel physicians' strike on the treatment and outcome of acute appendicitis in Jerusalem. Isr J Med Sci 1990;26(10):559-563.

. Aro S, Hosia P. Effects of a doctors' strike on primary care utilization in Varkaus, Finland. Scand J Prim Health Care 1987;5(4):245-251.

4. Bukovsky I, Herman A, Sherman D, Schreyer P, Arieli S, Caspi E. Perinatal outcome following physicians' strike of 1983. Isr J Med Sci 1985;21(10):804-807.

5. Gruber J, SA Kleiner. Do Strikes Kill? Evidence from New York State. NBER Working Paper Series, Vol. w15855. Cambridge MA, USA: NBER, March 2010.

6. Siegel-Itzkovich J. Doctors strike in Israel may be good for health. BMJ 2000;320(7249):1561.

6. Siegel-Itzkovich J. Doctors strike in Israel may be good for health. BM) 2000;320(7249):1561.
7. Erceg M, Kujundzic-Tiljak M, Barbic-Erceg A, Coric T, Lang S. Physician`s strike and general mortality: Croatia 's experience of 2003. Coll Antropol 2007;31(3):891-895.

Accepted 15 June 2012. 